\title{
EVALUATION OF RISK FACTORS AFFECTING ANASTOMOTIC LEAKAGE AFTER REPAIR OF ESOPHAGEAL ATRESIA
}

\author{
Avaliação dos fatores de risco que afetam deiscência de anastomose após reparação de atresia esofágica
}

Shahnam ASKARPOUR, Mehran PEYVASTEH, Hazhir JAVAHERIZADEH, Nasim ASKARI

From the Department of Pediatric Surgery, Imam Khomeini Hospital, Ahvaz Jundishapur University of Medical Sciences, Ahvaz, Iran

HEADINGS - Anastomosis. Anastomotic leak. Esophageal atresia.
ABSTRACT - Background: Anastomotic leak are reported among neonates who underwent esophageal atresia. Aim: To find risk factors of anastomotic leakage in patients underwent esophageal repair. Methods: All cases with esophageal atresia were included. In this case control study, patients were classified in two groups according to presence or absence of anastomotic leaks. Duration of study was 10 years. Results: Sixty-one cases were included. Mean $\pm S D$ age at time of surgery in patients with leakage and without leakage was $9.50 \pm 7.25$ and $8.83 \pm 6.93$ respectively $(p=.670)$. Blood transfusion and two layer anastomosis had significant correlation with anastomotic leakage. Conclusion: Blood transfusion and double layer anastomosis are associated with higher rate of anastomotic leakage.

\section{Correspondence:}

Shahnam Askarpour

E-mail: Shahnam_askarpour@yahoo.com

Financial source: University of Medical Sciences, Ahvaz, Iran

Conflicts of interest: none

Received for publication: 19/02/2015 Accepted for publication: 12/05/2015

DESCRTORES: Anastomose. Fístula. Atresia do esôfago.
RESUMO - Racional: Fístulas são relatadas entre os recém-nascidos que foram submetidos à reparação de atresia de esôfago. Objetivo: Encontrar fatores de risco de deiscência de anastomose nos pacientes submetidos à correção cirúrgica do esôfago. Métodos: Todos os casos com atresia de esôfago foram incluídos. Neste estudo caso-controle, os pacientes foram classificados em dois grupos de acordo com a presença ou ausência de fístula. Duração do estudo foi de 10 anos. Resultados: Sessenta e um casos foram incluídos. A média $\pm D P$ da idade no momento da operação em pacientes com deiscência e sem foi 9,50 7,25 e 8,83 $\pm 6,93$, respectivamente $(p=0,670)$. Transfusão de sangue e duas camadas anastomose tiveram correlação significativa com a deiscência da anastomose. Conclusão: Transfusão de sangue e anastomose em dois planos estão associadas com maior taxa de deiscência.

$\mathrm{T}$ he overall incidence of esophageal atresia ranges from $1 / 2500$ to $1 / 4000$ live births. Anastomotic leaks occur in $15-20 \%$ of patients. Several factors may play a role in pathophysiology of leaks such as: friable lower segment, ischemia of the esophageal ends, sepsis, poor suturing techniques, the type of suture, and excess anastomotic tension ${ }^{12}$. Anastomotic leakage may be associated with some complications. Peyvasteh et al. ${ }^{8}$ showed incidence of stricture significantly higher in patients who developed anastomosis leak after repair ${ }^{2}$. There are few published papers about anastomotic leakage after repair of esophageal atresia.

The aim of this study was to find possible factors which may play a role in anastomotic leaks after surgical repair of esophageal atresia.

METHODS

This study was realized at the Department of Pediatric Surgery of Imam Khomeini Hospital of Ahvaz Jundishapur, University of Medical Sciences, Ahvaz, Iran, and was approved by ethical committee of the university

All cases with esophageal atresia were included. Gross classification was used for classification of esophageal atresia. In this case control study, patients were classified in two groups: with and without anastomotic leakage.

SPSS version 13.0 (Chicago, IL, USA) was used for data analysis. t-Test and ChiSquare were used for comparison.

Sixty-one cases were included. Mean age $\pm S D$ at the time of surgery in patients with anastomotic leakage and without was $9.50 \pm 7.25$ and $8.83 \pm 6.93$ days, respectively $(p=0.670)$. 
TABLE 1 - Analysis of factors among children with and without leakage

\begin{tabular}{|c|c|c|c|c|}
\hline & & $\begin{array}{c}\text { With } \\
\text { Leakage } \\
n=13\end{array}$ & $\begin{array}{l}\text { Without } \\
\text { Leakage } \\
(n=48)\end{array}$ & $\mathrm{p}$ \\
\hline Sex & $\begin{array}{l}\mathrm{F} \\
\mathrm{M}\end{array}$ & $\begin{array}{l}5(16.1 \%) \\
8(26.7 \%)\end{array}$ & $\begin{array}{l}26(83.9 \%) \\
22(73.3 \%)\end{array}$ & 0.363 \\
\hline Blood transfusion & $\begin{array}{l}0 \\
1 \\
2\end{array}$ & $\begin{array}{c}1(5.3 \%) \\
9(24.3 \%) \\
3(60 \%)\end{array}$ & $\begin{array}{c}18(94.7 \%) \\
28(75.7 \%) \\
2(40 \%)\end{array}$ & 0.023 \\
\hline $\begin{array}{l}\text { Technique of } \\
\text { anastomose }\end{array}$ & $\begin{array}{l}\text { One Layer } \\
\text { Two Layer }\end{array}$ & $\begin{array}{l}9(16.4 \%) \\
4(66.7 \%)\end{array}$ & $\begin{array}{c}46(83.6 \%) \\
2(33.3 \%)\end{array}$ & 0.016 \\
\hline Type of atresia & $\begin{array}{l}A \\
B \\
C\end{array}$ & $\begin{array}{c}2(40.0 \%) \\
1(25.0 \%) \\
10(19.2 \%)\end{array}$ & $\begin{array}{c}3(60.0 \%) \\
3(75.0 \%) \\
42(80.8 \%)\end{array}$ & 0.547 \\
\hline Gap length & $\begin{array}{l}\text { Long } \\
\text { Short }\end{array}$ & $\begin{array}{l}5(35.7 \%) \\
8(17.0 \%)\end{array}$ & $\begin{array}{c}9(64.3 \%) \\
39(83.0 \%)\end{array}$ & 0.131 \\
\hline Thoracotomy type & $\begin{array}{l}\text { Extrapleural } \\
\text { Intrapleural }\end{array}$ & $\begin{array}{c}12(24.5 \%) \\
1(8.3 \%)\end{array}$ & $\begin{array}{l}37(75.5 \%) \\
11(91.7 \%)\end{array}$ & 0.209 \\
\hline $\begin{array}{l}\text { Pre-operation } \\
\text { pneumonia }\end{array}$ & $\begin{array}{l}\text { Yes } \\
\text { No }\end{array}$ & $\begin{array}{c}12(24.5 \%) \\
1(8.3 \%)\end{array}$ & $\begin{array}{l}37(75.5 \%) \\
11(91.7 \%)\end{array}$ & 0.209 \\
\hline $\begin{array}{l}\text { Pre-operation } \\
\text { WBC }\end{array}$ & & $15.023 \pm 4.60$ & $12.95 \pm 4.35$ & 0.164 \\
\hline Pre-operation $\mathrm{Hb}$ & & $13.90 \pm 2.75$ & $14.07 \pm 2.36$ & 0.84 \\
\hline $\begin{array}{l}\text { Starting oral } \\
\text { feeding after } \\
\text { surgery (day) }\end{array}$ & & $8.92 \pm 7.12$ & $7.48 \pm 3.02$ & 0.488 \\
\hline $\begin{array}{l}\text { Pre-operation } \\
\text { hospitalization } \\
\text { time (day) }\end{array}$ & & $6.08 \pm 4.85$ & $6.62 \pm 4.75$ & 0.7 \\
\hline $\begin{array}{l}\text { Age at operation } \\
\text { (day) }\end{array}$ & & $9.50 \pm 7.22$ & $8.83 \pm 6.93$ & .29 \\
\hline $\begin{array}{l}\text { Body } \\
\text { weightv(gram) }\end{array}$ & & $2755 \pm 710$ & $2865 \pm 379$ & 0.5 \\
\hline
\end{tabular}

Anastomotic leakage had positive correlation with blood transfusion $(p=0.023)$ and two layer anastomosis $(p=0.016)$. There were no significant differences between both groups in terms of gender, type of atresia, gap length, pre-operation hemoglobin and pre-operation pneumonia (Table 1)

\section{DISCUSSION}

In this study of 61 cases, 13 (21\%) had anastomotic leakage. In Peyvasteh et al. ${ }^{3}$ study from Tehran, Iran, anastomotic leakage was reported in 18 (24.32\%) of 74 patients. Chittmittrapap et al. ${ }^{3}$ reported that anastmosis leakage was present in $17 \%$ of cases. In Konkin et al. ${ }^{4}$ study, anastomotic leakage was reported in $8 \%$ of cases. Anastomotic leakage was reported about $15-20 \%$ in other studies $5,6,9,10,11$. Anastomotic leakage rate of this study was similar to other reports.

Incidence of esophageal leak had significant difference according to atresia type ${ }^{12}$. But in this study, there was no significant difference. There was no relationship between the type of thoracotomy and leakage of anastomosis. This is similar to Askarpour et al. ${ }^{1}$ report.
Double layer anastomosis was significantly associated with anastomotic leakage. In Aslam et al. ${ }^{2}$ paper, was related no difference between single versus double layer anastomosis regarding leakage.

Limitations of this report are mainly connected on being a retrospective analysis and, also, realized in a single center.

\section{CONCLUSION}

Blood transfusion and two layer anastomosis were associated with anastomotic leakage in esophageal atresia in children

\section{ACKNOWLEDGMENTS}

This paper was issued from general physician thesis of Dr. Nasim Askari and supported by research affairs of Ahvaz Jundishapur University of Medical Sciences.

\section{REFERENCES}

1. Askarpour S, Ostadian N, Bahreini A. Evaluation of Two Surgical Methods (Extrapleural and Transpleural) in the Treatment of Neonates with Esophageal Atresia. The Internet Journal of Surgery. 2008;21(2).

2. Aslam V, Bilal A, Khan A, Bilal M, Zainulabideen, Ahmed M. Gastroesophageal anastomosis: single-layer versus double-layer technique--an experience on 50 cases. Journal of Ayub Medical College, Abbottabad : JAMC. 2008;20(3):6-9.

3. Chittmittrapap S, Spitz L, Kiely EM, Brereton RJ. Anastomotic leakage following surgery for esophageal atresia. Journal of pediatric surgery. 1992;27(1):29-32.

4. Konkin DE, O'HaliWA, WebberEM, Blair GK. Outcomes in esophageal atresia and tracheoesophageal fistula. Journal of pediatric surgery. 2003;38(12):1726-9.

5. Kovesi T, Rubin S. Long-term complications of congenital esophageal atresia and/or tracheoesophageal fistula. Chest. 2004;126(3):915-25.

6. Mortell AE, Azizkhan RG. Esophageal atresia repair with thoracotomy: the Cincinnati contemporary experience. Seminars in pediatric surgery. 2009;18(1):12-9.

7. Peyvasteh $M$, Askarpour $\mathrm{S}$, Sarmast $\mathrm{MH}$, Javaherizadeh $\mathrm{H}$, Mehrabi $\mathrm{V}$, Ahmadi J, et al. Esophageal atresia: comparison between survivors and mortality cases who underwent surgery over a 2-year period in two referral hospitals, Tehran, Iran. Annals of Pediatric Surgery. 2012;8(2):42-4 10.1097/01.XPS.0000412346.91254.0e.

8. Peyvasteh M, Askarpour S, Shoushtari S. A study of esophageal strictures after surgical repair of esophageal atresia. Pak J Med Sci. 2006;22(3):269.

9. Rintala RJ, Sistonen S, Pakarinen MP. Outcome of esophageal atresia beyond childhood. Seminars in pediatric surgery. 2009;18(1):50-6.

10. Sharma AK, Shekhawat NS, Agrawal LD, Chaturvedi V, Kothari SK, Goel D. Esophageal atresia and tracheoesophageal fistula: a review of 25 years' experience. Pediatric surgery international. 2000;16(7):478-82.

11. Spitz L. Oesophageal atresia. Orphanet journal of rare diseases. 2007;2:24.

12. Upadhyaya VD, Gangopadhyaya A, Gupta D, Sharma S, Kumar V, Pandey A, et al. Prognosis of congenital tracheoesophageal fistula with esophageal atresia on the basis of gap length. Pediatric surgery international. 2007;23(8):767-71. 